\title{
Disaster Preparedness of Çankırı Museum Building (Turkey) Converted from a Historical Building
}

\author{
Fatma Sezin DOĞRUER ${ }^{1}$
}

\begin{abstract}
Converted from a historical building, Çankırı Museum is one of the immovable cultural properties used as a museum. Within the context of this study, the brief history, structural and spatial features of the building, and the restoration and exhibition works carried out in the museum were examined. As a con-tribution to the risk assessments in which human health is priority, the disaster risks for the museum artifacts and the historical buildings where the artifacts are exhibited, and also the necessary architec-tural precautions to be taken in the historical museum structure are discussed in the study. Çankırı Mu-seum is chosen as an exemplary for the disaster preparedness due to its historical identity and its recent restoration and exhibition work. Evaluation on the disaster preparedness of the museum building was made by using the prepared tables. The methodology proposed in this study depends on a grading sys-tem to determine if the museum and the artifacts are safe or not against disasters, according to the data in the tables. The aim of the proposed method that would be a model for the further studies is to deter-mine the level of protection against disasters numerically. Within the scope of the study, the proposed method is used to evaluate the risk situation of the Çankırı Museum; and it is determined that the neces-sary precautions were taken at a high rate in the museum structure.
\end{abstract}

Keywords: Çankırı Museum, Disaster Preparedness, Museum Risks, Museology

\section{Tarihi Yapıdan Dönüştürülen Çankırı Müzesi Binasının (Türkiye) Afet Hazırlıklılığı}

\begin{abstract}
Özet
Tarihi yapıdan dönüştürülen Çankırı Müzesi, müze olarak kullanılan taşınmaz kültür varlıklarındandır. Bu çalışma kapsamında müzede gerçekleştirilen restorasyon ve sergileme çalışmalarının kısa tarihçesi, yapısal ve mekansal özellikleri incelenmiștir. İnsan sağlığının öncelikli olduğu risk değerlendirmelerine katkı olarak, müze eserleri ve sergilendikleri tarihi yapılar için afet riskleri ile tarihi müze yapısında alınması gereken mimari önlemler de ele alınmıştır. Çankırı Müzesi, tarihi kimliği ve son yıllardaki restorasyon ve teşhir çalışmaları nedeniyle afet hazırlıklıı̆ı̆ı için örnek olarak seçilmiştir. Hazırlanan tablolar kullanılarak müzenin afet hazırlıklılığı hakkında değerlendirme yapılmıştır. Bu çalışmada öner-ilen metodoloji, tablolardaki verilere göre, müze ve eserlerin afetlere karşı güvenli olup olmadığını be-lirlemeye yönelik bir puanlama sistemine dayanmaktadır. Sonraki çalışmalara model oluşturmak üzere önerilen yöntemin amacı afetlere karşı korunma düzeyinin sayısal olarak tespit edilmesidir. Çalışma kapsamında önerilen yöntem, Çankırı Müzesi'ndeki risk durumunu değerlendirmek için kullanılmıştır ve müzede gerekli önlemlerin yüksek oranda alındığı tespit edilmiştir.
\end{abstract}

Anahtar Kelimeler: Çankırı Müzesi, Afet Hazırlıklılı̆̆ı, Müze Riskleri, Müzecilik

\footnotetext{
${ }^{1}$ Dr., Republic of Turkey Ministry of Culture and Tourism, Directorate General of Cultural Assets and Museums, Ankara e-mail: sezin.dogruer@hotmail.com ORCID No: 0000-0002-1237-0020
}

*Permission for the case study and the use of visual materials has been taken by the 12.01.2021 dated and E.53688332-107-1033441 numbered letter of Directorate of Çankırı Museum for this study. 


\section{INTRODUCTION}

Disaster is defined as a natural, technological and human related happening that causes physical, social, environmental and economic damage, and cannot be coped in local scale (URL 3; Kuzucuoğlu, 2010; Sungay, 2012). Earthquake, landslide, fire, flood, tsunami, volcanic action and rock falls are some disaster types. Hazard is "a naturally occurring phenomenon or a human induced event" (URL 8). It is defined as happening, a material or a situation that causes social, economic and environmental troubles; and injury, death or other health problems by some researchers (Kuzucuoğlu, 2010; Sungay, 2012). Hazards, which do harm to the museum buildings and their collection, are classified as location-related and structure-related hazards. Risk is defined as the possibility of something's occurrence with negative impact. There are risks concerning the use and preservation of historical buildings (Pedersoli \& Antomarchi, 2016). Another term used in disaster management is vulnerability, which is dependent on the inherited, socio-economic and institutional aspects of the cultural heritage or artifact (URL 8).

Museums are the organizations in the service of the community without making profit, which creates exhibitions for work, education and pleasure; protects, investigates and promotes the artifacts of excavations (Kökten, 2007). Deterioration which cannot be detected during day but can be increased by accumulation over time, and abrupt damages could be prevented and / or limited in scope of risk management in museums (National Park Service, 2006). By risk management, the vulnerability of the artifacts in terms of every agent of deterioration should be detected and grouped; accordingly the practices of conservation should be done in phases (Doğruer, 2019). The risks and the vulnerability of the artifacts because of these risks should be analyzed; the priorities for risk mitigation techniques should be determined (Roberts and Hutchins, 2009). Prevention of hazards, mitigation of impact of hazards, reducing vulnerability of cultural heritage and capacity building works are some of the methodologies for prevention and mitigation of disaster risks for cultural heritage (URL 8).

International Council of Museums, Code of Ethics contains articles (1.6 and 2.21) about developing policies in order to protect the museum's collection from natural and human-related disasters (ICOM, 2017). Risk mitigation constitutes the first phase of the disaster management, which involves activities such as response to infrastructure, structural and non-structural elements, structural analysis; and strengthening (Sungay, 2012). Interventions relating to risk mitigation can be classified as urgent, short-term and long-term according to the quality of the intervention and the responder. Firstly, the urgent implementations can be described as the simultaneous implementations on site by museum personnel with a low cost. Secondly, productions and mountings that need expertise, time and resource are some of the short-term implementations. Lastly, the long-term implementations are the ones comprising education and applications that need long period and big amount of budget to carry out (Podany, 2001).

When the museum designs are examined, it is seen that museum buildings are established by converting buildings with different purposes into museums afterwards or constructing buildings which are designed as museums. Historical buildings or today's buildings are both used in the conversion.

The museology works in Turkey focuses especially on adaptive reuse of the historical buildings. In this way, immovable cultural heritage is kept alive by using them as a museum. The basic principle is to interpret and present the monumental cultural property as an element of exhibition and thus to raise awareness on the people on the values of cultural property (Özkan Yazgan, 2011). In other words, the reuse of the historical buildings by adapting them to museums ensures recognition of these historical buildings and awareness of conservation. 
Anatolian Civilizations Museum (Ankara), Topkapı Palace Museum (Istanbul), Istanbul Turkish and Islamic Arts Museum, Bursa Turkish and Islamic Arts Museum, Çankırı Museum, Lycia Civilizations Museum (Antalya), Burdur Natural History Museum, Kars Caucasian Front Military History Museum and Silifke Atatürk Mansion and Ethnography Museum (Mersin) constitute some of the Turkish examples of the converted museums from historical buildings. Besides these, some of the historical buildings are used as monumental museums, and the historical building itself is served as the museum since no collection is exhibited inside. St.Nicholas Monumental Museum (Demre, Antalya) and Taksiyarhis Monumental Museum (Balıkesir) could be given as examples from Turkey (Doğruer, 2019). The museum types differ according to the building types. For the sake of example, the monumental historical buildings are mostly reused as archaeological museums; and, timber framed historical buildings of civil architecture are generally used as city museums or ethnographic museums, looking at the museums in Turkey.

While historical buildings are used as museums, architectural features of the museums can generate special environmental problems. Indoor environmental control of historical buildings can be provided through mechanical systems. As a matter of fact, the renewal or rehabilitation of the heating, ventilation, electricity, lighting, sanitary systems of the historical buildings is a necessity (Cassar, 1999; Liston, 2000). Capable specialists of cultural heritage and disaster management should jointly enhance tools for periodical inspection of historical buildings' structural soundness for protection against seismic movements for preserving their values and use proper technologies that would preserve these values over time (URL 5). Preventive conservation works firstly include investigation of the building, then the elaborate works of experts such as an architect, architectural conservator and a restoration expert (Appelbaum, 1991) at building scale. It should be noted that professions are not limited with this scale; preventive conservation also comprises preventive works on artifacts, textiles, manuscripts, and studies like information management, documentation and logistics.

In the cases where a historical building has been converted into a museum, the historical building should be considered as the most important part of the collection and priority should be given to its protection. The building itself should be protected from the deteriorations by taking necessary precautions (Kökten, 2007). Otherwise, the problems of the museums converted from historical buildings provide a basis for the problems of the artifacts. Those are physical deformations because of physical forces, fire, water entering the building, and incorrect relative humidity and temperature and pests (Canada Conservation Institute, 2015).

Turkey, having experienced various catastrophes, has followed international development and has prepared significant works on disaster management. 1999 Izmit earthquake was a turning point and an important date in terms of Turkey's risk management. Istanbul Seismic Risk Mitigation and Emergency Preparedness Project (ISMEP) was an important project that aimed to mitigate the seismic risks threatening the cultural heritage in Istanbul (URL 7). International Symposium of Cultural Heritage Protection in Times of Risk- Challenges and Opportunities was held in November 2012 by Yildiz Technical University and International Scientific Committee on Risk Preparedness (ICORP) (URL 10). This symposium comprised the studies on natural and human sourced risks on cultural heritage. International Symposium of Earthquake Risk Management of Historical Structures was held in October 2017 by General Directorate for Foundations (URL 11). As a result of the symposium, a guideline was prepared for the earthquake risk management for the historical buildings. Following the earthquakes in Turkey in recent years, "Damage Assessment Pilot Study on Cultural Heritage After Disaster" was conducted around İzmir and Aydin in order to be as a model for the probable disasters, in accordance with the 10th article of the law numbered 2863; under the coordination of the Ministry of Culture and Tourism, General Directorate of Cultural Heritage and Museums and the General Directorate of Foundations, in collaboration with Ministry of Interior, Disaster and Emergency Management Presidency (AFAD), expert team of volunteers from ICORP Turkey. In this context, a preliminary study of "Risk 
Assessment and Reduction of Damage" has been done for the museums under the responsibility of the General Directorate of Cultural Heritage and Museums in 2021. Following this preliminary study, restoration works are going to be evaluated for future studies. Within the scope of the evacuation of museums in Turkey in the events of disaster and emergency, identification studies about the weights and areas of the artifacts, packaging, transportation and storage conditions has been also carried out (General Directorate for Cultural Heritage and Museums, 2021). As mentioned by ICORP, cultural heritage ought to be inserted into the protocols and strategies of disaster planning and response through more extensive collaboration and co-operation between the government, intergovernmental organizations, nongovernmental organizations and the military (URL 6).

\section{MATERIALS AND METHODS}

While preparing the study, guideline publications and standards in the literature were searched; information, document research and interviews were conducted by the author with the staff of museum and directorate for surveying and monuments.

Evaluation of the disaster preparedness of the selected museum was made by the use of the prepared assessment tables developed by the author. These disaster preparedness tables provide data about the disasters that may pose risks in the historical building, the probable reasons, the exposures and the precautions taken / to be taken against the disasters. The mentioned hazards are about both the condition of the museum artifacts and the historical building. The condition of the historical building affects the condition of the inner environment of the museum; and this can cause improper relative humidity and temperature and cause damage on the artifact. Ensuring safety of the museum personnel and visitors is another crucial issue however; it is not included in this article. The procedure for the education and human-response is also an exception; the precautions on museum structures before disasters are explained. Another restraint of the article is that it did not comprise during and after disaster procedures.

The information used while composing the tables are based on the information in the framework for prevention of collections prepared by Canadian Conservation Institute (2015). This source was chosen because it is a profound reference both the natural disasters and the human related disasters were taken into consideration. Also, the disaster preparedness is evaluated relating to location and the building itself. This reference was not used directly. To clarify, the additions and formations for historical buildings were made by the author according to the other guide references.

The tables are not prepared only for Çankırı Museum, they are also applicable to the other museum buildings converted from historical buildings. Çankırı Museum is selected as an exemplary because of its historical context and its recent restoration and exhibition works, which are important in terms of being a guide for future studies.

The methodology proposed to determine if the museum and the artifacts are safe or not according to the data obtained from the research depends on a grading system. With this evaluation system, it is aimed to determine the level of protection against disasters numerically. A system of 100 is used in evaluation while grading. Total number of the rows including the 'disasters' likely to happen (stated in Table 2 and Table 3 ) is stated as the 'disaster number' (D). This value is the sum of the disaster number in Table 1 and Table 2 (Equation 1). Initially, 100 is divided to the disaster number (D). It is accepted as the 'disaster value' (DV) (Equation 2). In addition, the 'disasters' that are not applicable for the case study are out of scope. Eventually; it is expected to obtain 'disaster value' by this transaction. 
For every 'disaster', a number of 'precautions on museum structure' is suggested in the tables. The 'precaution value' (PV) for the every fulfilled 'precaution' is calculated by dividing the 'disaster value' (DV) to the number of the 'precautions on museum structure' (P) (Equation 3 ). ${ }^{2}$ The unfulfilled precaution has zero $(0)$ value.

The sum of the values Disaster Preparedness Level (DP) is evaluated within the system of 100 as very low, low, medium, high and very high degrees according to Table 1 . To clarify, DP is the sum of the 'Disaster Preparedness Level relating to Location' (DPL) and the 'Disaster Preparedness Level relating to Building' (DPB) (Equation 6).

Table 1. Disaster Preparedness Level (DP)

\begin{tabular}{ll}
\hline $0-20$ & Very Low -Very little precautions have been taken against disasters \\
\hline $21-40$ & Low-Limited precautions have been taken against disasters, but not adequate \\
\hline $41-60$ & Medium-The precautions have been taken against disasters in a medium scale \\
\hline $61-80$ & High-The necessary precautions are taken for the disasters to a high rate \\
\hline $81-100$ & Very High-The necessary precautions are taken for the disasters to a great extent \\
\hline
\end{tabular}

It is necessary here to clarify exactly what is meant by DPL and DPB. Firstly, DPL is the sum of the values of 'Earthquake', 'Fire', 'Flood', 'Landslide', 'Tsunami', 'Volcanic Action' and 'Rock falls' as mentioned in Table 2 (Equation 4). Secondly, DPB is defined as the sum of the values of 'Earthquake', 'Fire' and 'Flood' as mentioned in Table 3 (Equation 5). ${ }^{4}$ Equations are stated in the Part 3 in detail.

\section{FINDINGS AND DISCUSSION}

\section{1. Çankırı Museum}

\subsubsection{Historical survey}

Çankırı Museum (Çankırı, Turkey) is located in Çankırı city center, in the Central Anatolia region of Turkey. Firstly, the ground floor of the Public Education Center (Halkevi) was organized as a museum in 1972. The museum was temporarily moved to Çankırı High School due to the demolition of the Halkevi for the purpose of building a cultural center in 1976. After the completion of the Centennial Cultural Center in 1981, the museum was relocated in this building (Figure 1) (URL 2).

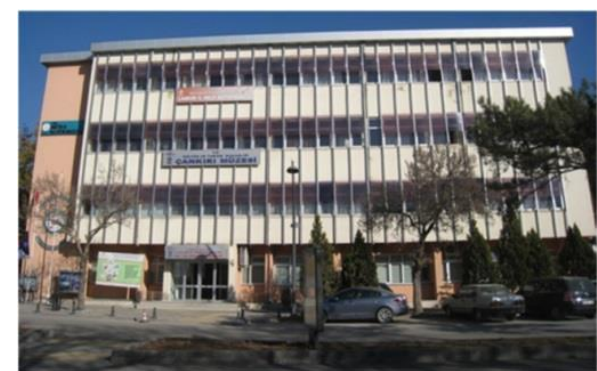

(Outside)

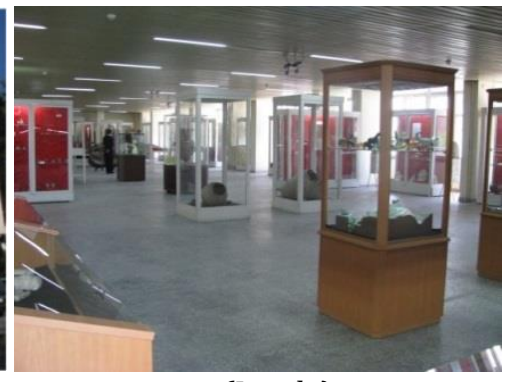

(Inside)

Figure 1. Museum at the Centennial Cultural Center (Kocaeli, 2017).

\footnotetext{
2 The 'precaution value' is unique for every row of precautions against every disaster.

${ }^{3}$ The tables are not prepared only for Çankırı Museum, they are also applicable to the other museum buildings converted from historical buildings, so that terms such as 'tsunami' and 'volcanic action' are used in the tables.

${ }^{4}$ The formulas are going to be mentioned in the 'Discussion' section.
} 
Due to the increase in the number of artifacts in the museum and the inadequate physical conditions of the museum, the museum was moved to the Former Government House of Çankırı in 2017 (Figure 2).

The building is known to have been built in 1903-1905 in the Ottoman period (the period of Abdülhamid the second) by Kastamonu Governor Enis Pasha (Duymaz, 2003). It was registered on 14.01.1977 as an immovable cultural property (URL 1). It is stated in various sources that the Government House was demolished and rebuilt in the beginning of the $20^{\text {th }}$ century (Demircioglu, 1973; Topçubaşı, 2009). The building was used as the Government House till 1985 and as the Courthouse between 1985 and 2012 (Figure 3) (Figure 4) (General Directorate for Cultural Heritage and Museums, 2021). Between the years of 2014 and 2016, its conversion works including its restoration and exhibition design were conducted.

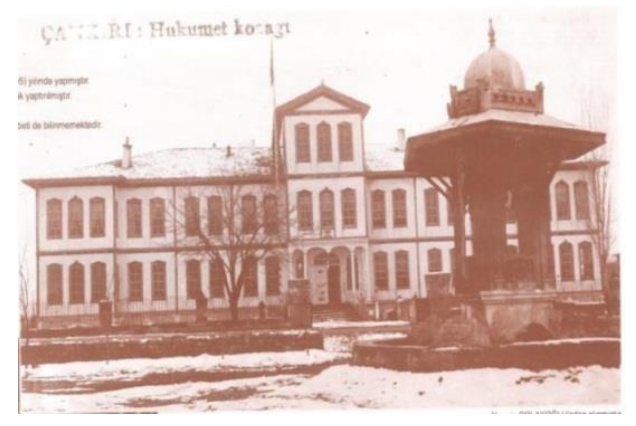

Figure 2. Former Government House (Demiröz, 2001).

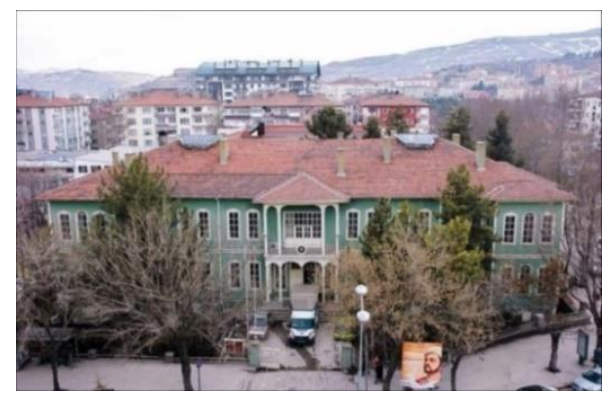

Figure 3. Former Courthouse before restoration works (General Directorate for Cultural Heritage and Museums, 2021).

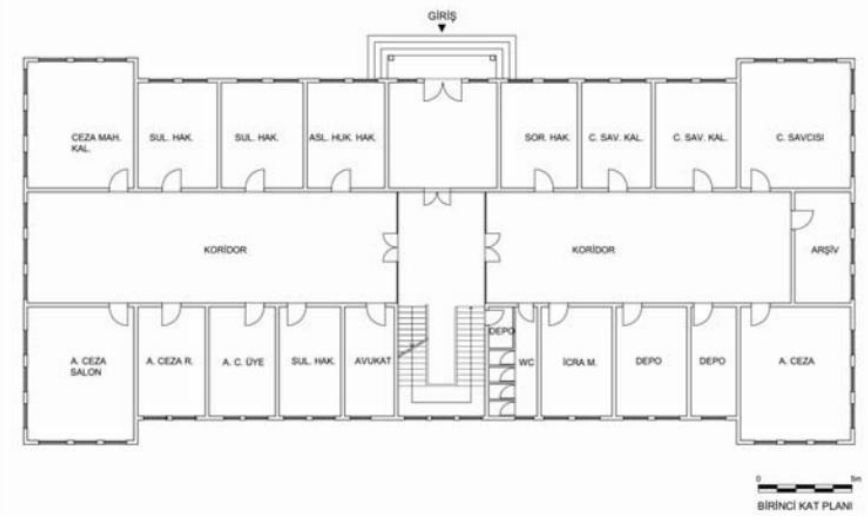

Figure 4. Previous plan scheme of Courthouse (Topçubaşı, 2009). 


\subsubsection{Architecture}

- Structural features: Çankırı Museum consists of a basement, two floors starting from the ground level and an attic (Figure 5). The basement is made of rubble stone walls, with cut stone in the corners. The ground floor is made of the timber framed system and mudbrick infill. The first floor consists of timber frame with baghdadi. It is understood that the architectural system of the building gets lighter while reaching the upper floors in the building. The building materials in the outer walls are solid blend bricks between the timber frame.

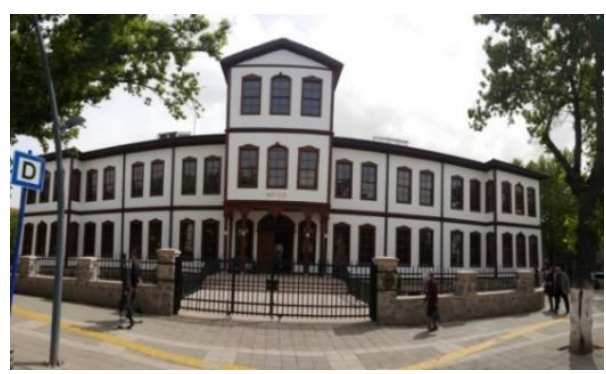

Figure 5. Çankırı Museum building (General Directorate for Cultural Heritage and Museums, 2021).

- Spatial features: The building has a rectangular symmetrical plan with four protrusions on the corners of the building and a sofa called corridor (Figure 6). The building entrance reached by a three-step staircases is a monumental wooden pillared entrance in the middle of the north facade. There is also a bay window above the entrance to highlight.

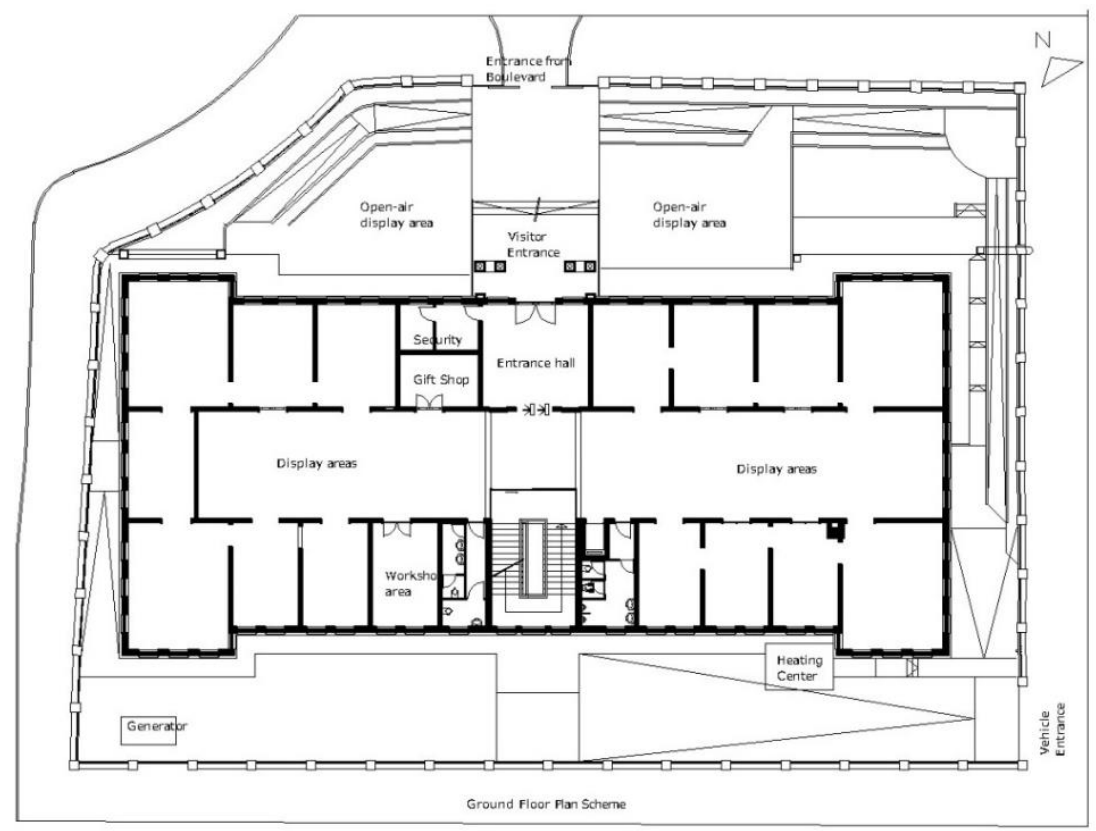

Figure 6. Current plan scheme of the museum ${ }^{5}$

1. Exhibition spaces: Çankırı Museum has a 3000 square meter closed and 600 square meter open exhibition area and consists of three sections: Natural History, Archaeology and Ethnography sections. Chalcolithic, Bronze Age, Hittite, Hellenistic, Roman and Eastern Roman artifacts are exhibited chronologically in the Archaeological Artifacts Section on the ground floor of the museum. In the Ethnography Section on the first floor of the museum, artifacts reflecting the sociocultural characteristics of the Çankırı region are exhibited. Thematically exhibited ethnographic

${ }^{5}$ Plan scheme was drawn by use of the drawings of Çankırı Museum in Archive of General Directorate for Cultural Heritage and Museums (Ankara, Turkey). 
artifacts are about 'Turkish-Islamic Artifacts, 'Traditional Kitchen and Kitchen Equipment', 'Weaving', 'Mevlevi Order', 'Weight Measuring Instruments', 'Yaran Culture', 'The Way of Independence', 'Traditional Clothing', 'Weapons', 'Medicine Healing' and 'Lighting' themes (URL 2). Within the scope of these themes, there are various visual display units (Figure 7). Showcases, niches and lighted-up information boards are used in the display (Figure 8).

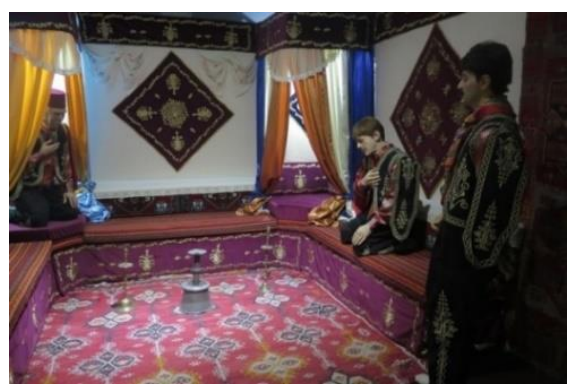

Figure 7. Visual display unit (URL 2).

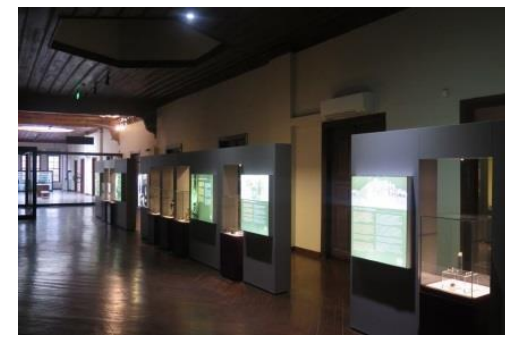

(Showcases)

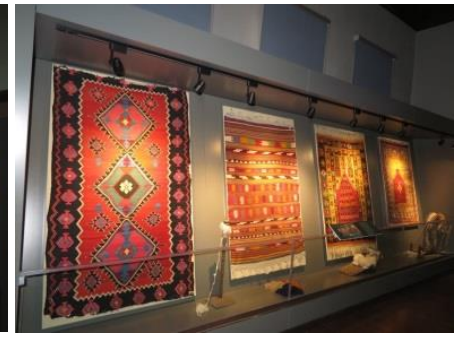

(Boards)

Figure 8. Showcases and boards (URL 4).

Instead of direct entrance to the museum exhibition spaces, an entrance hall has been designed in order to provide a controlled passage, to carry out welcoming activities (information, ticket purchase, cloakroom, security). Habitat recreations (human-burial culture, finding fire, giraffe and saber-toothed tiger skeletons) have been made in the corridors. In the Natural History Section, fossils dating to the Late Miocene period found at the "Çorakyerler Fossil Site Excavation" are exhibited (Figure 9.). During the restoration process, according to the structural calculation, spaces were opened in the interior walls between the sections to facilitate the circulation of the visitors. However those transitions did not affect to structural condition of the building.

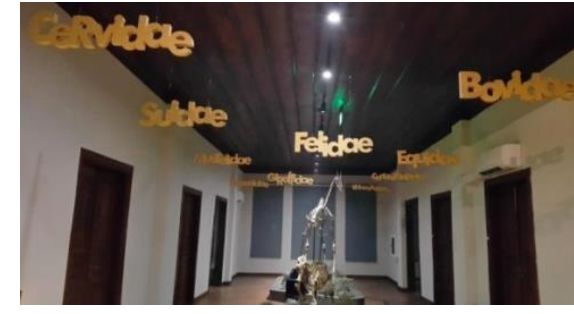

(National History Section)

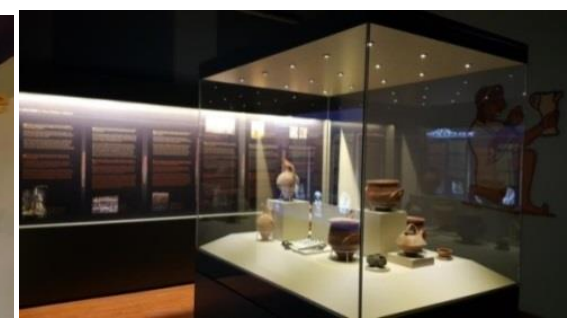

(Archaeology Section)

Figure 9. Exhibition Halls (URL 4).

On the first floor of the building, there is a temporary exhibition area of 100 square meter in the corridor. Moreover an open exhibition, a space for children's archaeology education and a research space take place at the open areas on the right and left sides of the visitor entrance on the north facade of the building. 
2. Artifact storage spaces: There are storage spaces, divided according to the types of the artifacts: archaeological artifacts, ethnographic artifacts and fossils, spread over an area of 600 square meter along the corridor of $5.80 \mathrm{~m}$ wide, on the basement floor (Figure 10). The entrance of storages is on the basement floor in the middle of the south facade of the building $(-3.00 \mathrm{~m}$. elevation). There are also artifacts acceptance and quarantine rooms used in the process of bringing artifacts to the museum building. On the basement floor, there is also another space used for taking photographs of artifacts and conducting preparations for exhibitions and transportation of artifacts (packaging, labeling).

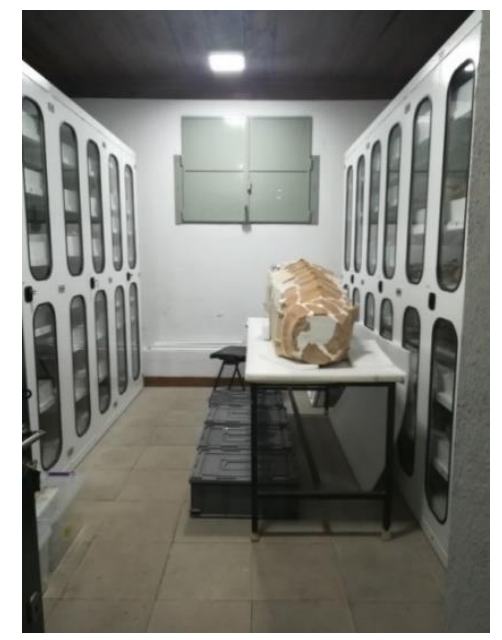

Figure 10. Artifact Storage Space (Ankara Directorate for Surveying and Monuments, 2021).

3. Laboratory: A laboratory space has been created to carry out the conservation of artifacts that require maintenance and repair work. Necessary changes such as the construction of a chimney system with double exhaust have been carried out during the restoration (General Directorate for Cultural Heritage and Museums, 2021).

4. Administrative unit: The administrative units are a director's room, a secretary's room, expert rooms, officers' rooms, a library used by the museum personnel and a meeting room on the first floor of the museum, in the west wing of the building, separated from the exhibition hall by a glass partition.

5. Social interaction space: The social interaction spaces are conference hall, cafeteria and workshop area where museum visitors are able to socially interact. A cafeteria was designed for visitors in the attic. Souvenir sales unit and children's education space take place on the right of the entrance on the ground floor. There is also a seminar and conference hall for fifty people on the first floor. A workshop space has been created on the basement floor to carry out activities peculiar to Çankırı, coin printing and stamp printing.

6. Technical rooms: There is a heating center on the basement floor. The east wing of the corridor on this floor is divided by a partition wall from the cafeteria for the staff and the wet areas, which are reached by a ramp on the east facade. The electrical room on the ground floor is connected with the security room. Generator and outdoor unit of the heating center are located in the garden.

7. Security units: There is a room for security personnel on the right side of the entrance on the ground floor and a closed circuit television (CCTV) system in the electrical room.

\subsubsection{Interventions}

Interventions were made at different times within the scope of using the Çankırı Museum building for different purposes (Figure 11). The building has undergone restoration that included works 
such as removing the cihannüma (Figure 12), replacing wooden stairs with reinforced concrete one, and installing a heating system while being used as a government house (Topçubaşı, 2009); and restoration works and ground reinforcement between 2014 and 2016 before it was converted into a museum. In addition, a structural evaluation report was prepared within the scope of the restoration works carried out in the building.

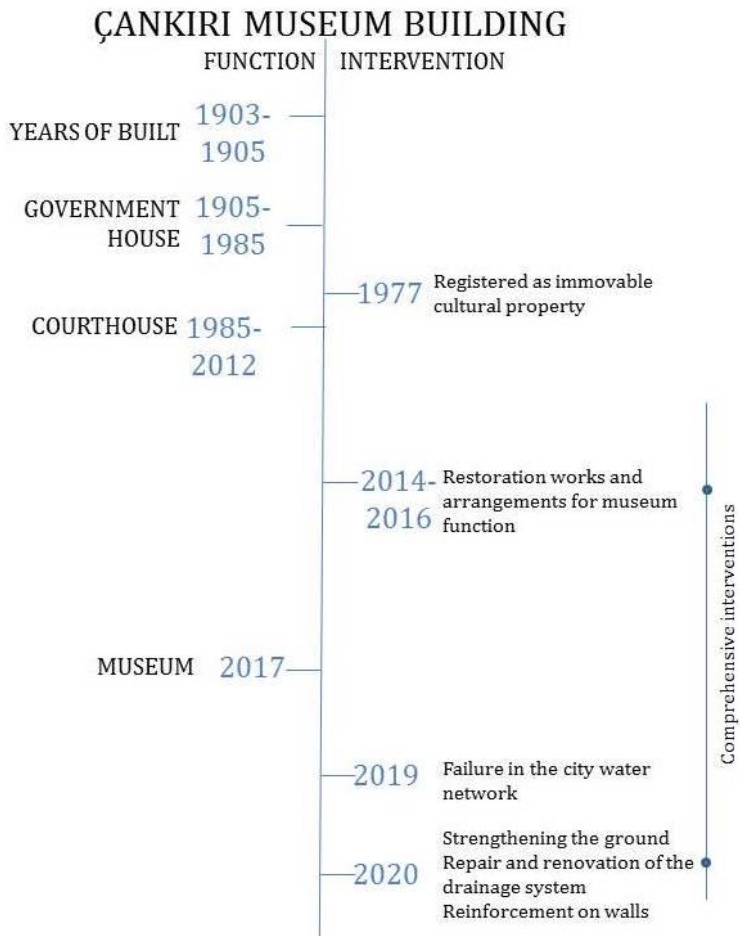

Figure 11. Demonstration of Functions and Interventions for Çankırı Museum

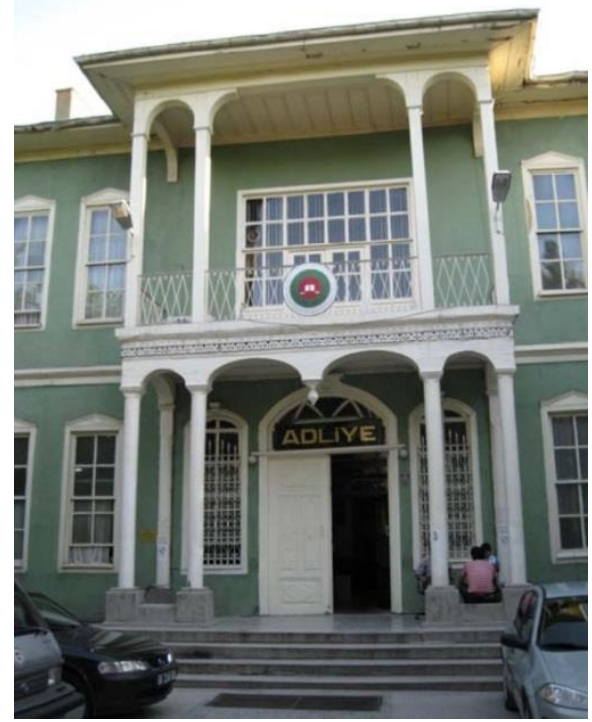

Figure 12. Çankırı Adliye building (Topçubaşı, 2009).

During the restoration work, it was understood that the load-bearing walls on the basement floors were intact, but there were decays in the timber framed system and also the infill material had lost its properties, which became evident after the plaster rasping made on the ground and the 
first floors (Figure 13). Meanwhile, heat insulation was used instead of any other infill in between the timber framed system. The building materials in the outer walls have not been changed.

At the same time, the bay window on the north facade was rebuilt on metal bearing beams and foundations due to decay in the wood material. After the structural strengthening of the building, a new drainage system was built around the building. Since there were decays in the wooden material, the roof has been renewed in its original form with hard and durable wood. During the restoration process, wooden doors and ceilings were preserved; maintenance was done and repairs were made (Figure 14). The rasping was applied on the walls in the interior spaces. In the exhibition spaces, the windows were closed in order to avoid the damage of daylight to the artifacts. The reinforced concrete staircase was covered with wooden steps to make it compatible with original form. The cracks in the stone walls were repaired using lime-based mortar.

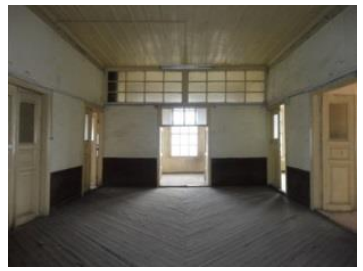

(Before restoration)

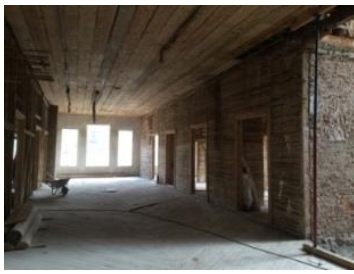

(During restoration)

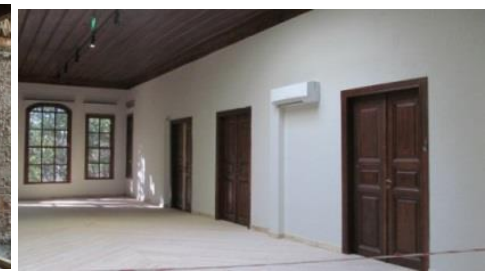

(After restoration)

Figure 13. Restoration works (General Directorate for Cultural Heritage and Museums, 2021).

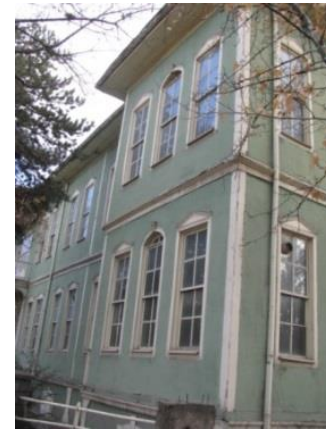

(Before restoration)

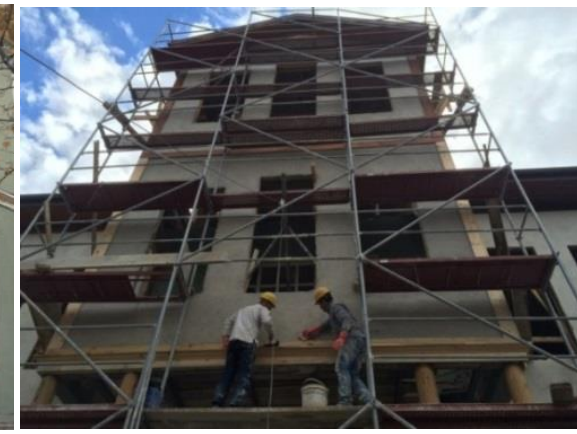

(During restoration)

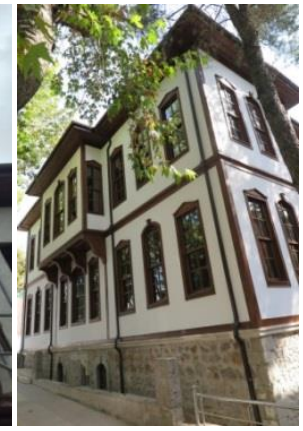

(After restoration)

Figure 14. Restoration works (Ankara Directorate for Surveying and Monuments, 2021).

\subsubsection{Disaster Preparedness}

Disaster preparedness will be evaluated in terms of the disasters of earthquake, fire, flood, landslide for Çankırı Museum. There are methods used in earthquake risk management such as determining the tolerable degree, identification of the hazard, approximation of the earth movement and possible responses of the site, building and the artifacts. Interdisciplinary work by seismologists, architects, structural engineers, geologists, conservators, designers and occupational safety specialists is necessary for earthquake assessments. Considering the earthquake and landslide risks arising from the location of the Çankırı Museum, the types of soil, being in the landslide area, earthquake zone and seismic movement were investigated as the reasons of hazard. It is reported on the ground reinforcement report (May 2019) that the Çankırı city center is on the $2^{\text {nd }}$ level according to earth movements; there is no harm in terms of liquefaction and mass movements problem for the area. It is not a landslide area, either. Because of the environmental problem caused by ground water in 2019, ground reinforcement projects have been implemented. Meanwhile the artifacts were stored in the former museum building until the ground reinforcement was completed. The museum was closed to visitors in 2019, due to deformations which resulted in deep cracks up to $5 \mathrm{~cm}$. on the load bearing walls caused by the land subsidence (approximately $10 \mathrm{~cm}$.) in the south of the museum building (Figure 15). By 
acoustic leak detection, the reason for the collapse of the foundation in the building was determined as a water leakage from a city network to the foundation. Firstly, drilling works were carried out at the basement in 2019 and a ground reinforcement report was prepared in May 2019. Examination holes were also excavated in order to obtain information about the foundation of the building (Ankara Directorate for Surveying and Monuments, 2021).

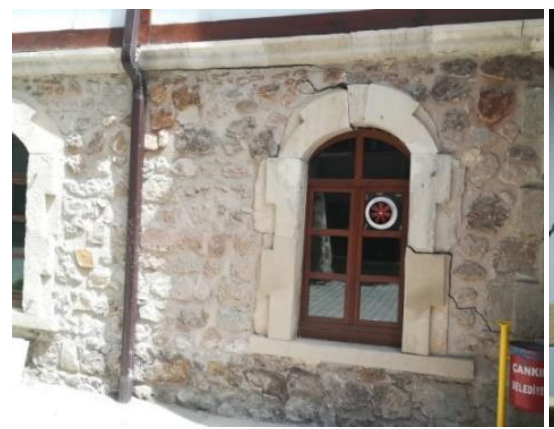

(Outside)

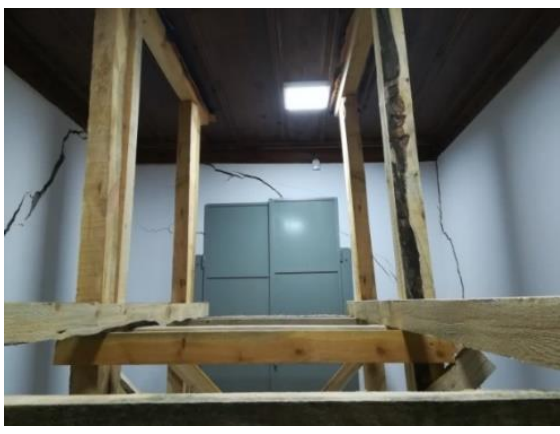

(Inside)

Figure 15. Cracks seen on the walls in 2019 (Ankara Directorate for Surveying and Monuments, 2021).

Before the reinforcement process, the building was suspended from the outside and inside to prevent a possible partial collapse in the eastern wall and its effects on the whole structure. Steel I-beams were used as scaffolding between the museum and the neighboring building outside; and wooden beams were used inside in order to provide stability while restoration (Figure 16).

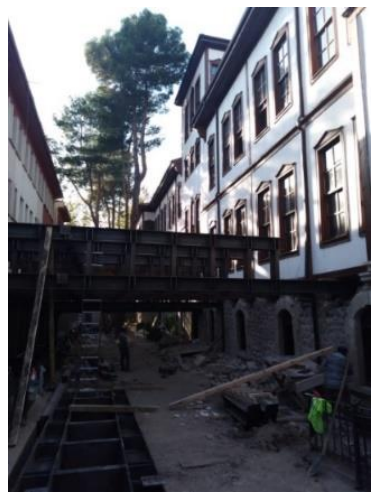

(Outside)

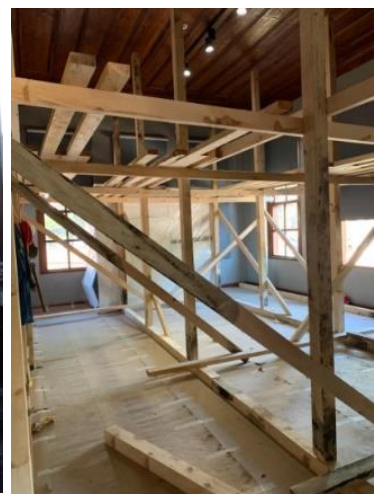

(Inside)

Figure 16. Scaffolding (Ankara Directorate for Surveying and Monuments, 2021).

Within the scope of the ground reinforcement works carried out in 2020, cement injection was made into the ground; reinforced concrete bored piles were applied; and crushed stone and poor concrete was laid on the ground. Subsequently, reinforced concrete support beams were built on the foundation. (Figure 17) (Ankara Directorate for Surveying and Monuments, 2021). It is recommended that as a precaution against earthquake, ground seismic base insulator applications (Canadian Conservation Institute, 2015), which are newly seen in world, could be used in historical building reconstruction projects and implementations more often.

The data to be used to evaluate the fire hazard arising from the location of the museum were obtained by examining the surrounding buildings, seasonal conditions and rainfall (National Park Service, 2006). During the evaluation; it has been determined that the buildings around the museum do not have a clear risk of fire regarding building materials. The area of the museum is not a high crime zone that may cause fire sabotage at museums. In the last forty years, the average maximum temperature in Çankırı has been measured as $31.2^{\circ} \mathrm{C}$ and the average minimum temperature has been measured as $-4.2^{\circ} \mathrm{C}$ (URL 9). Considering this information as a whole, it 
could be considered that the fire risk caused by high air temperature is low however, taking action is indisputably necessary. To ensure this, there is a manual fire extinguishing system in the museum. In addition, fire cabinets, fire tubes and smoke detectors are used.

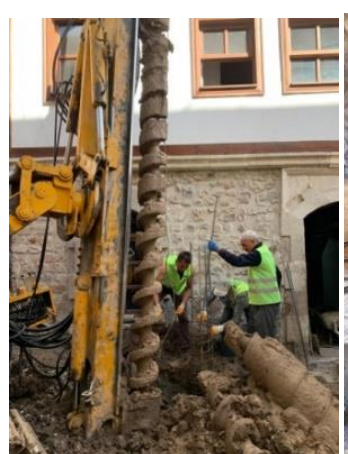

(Bored Pile)

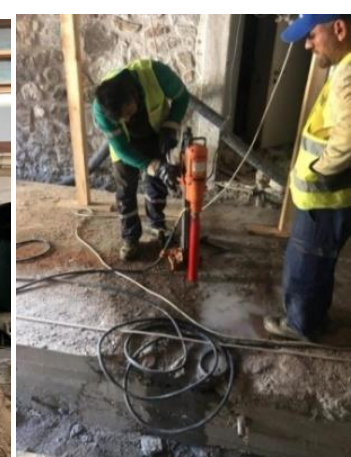

(Injection)

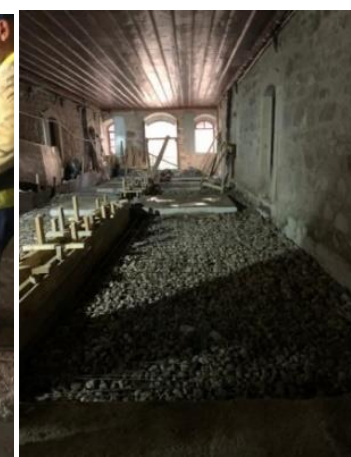

(Concreting)

Figure 17. Ground reinforcement in 2020 (Ankara Directorate for Surveying and Monuments, 2021).

Excess or variability in the amount of rain and snow are the environmental reasons of flood in museums (Canadian Conservation Institute, 2015). It has been understood that the area where the Çankırı Museum is located is not a streambed formerly. No severe meteorological events in the past are detected; maximum precipitation was measured as $73.7 \mathrm{~kg} / \mathrm{m}^{2}$ in 2011 (URL 9). The number of rainy days is found to be average. Although the drainage work was carried out during the restoration of the building between 2014 and 2016, moisture problem was observed in the artifact storage spaces in the basement afterwards. The ground survey conducted in 2019 revealed that there is a probability of underground water and surface water coming to the construction site. Therefore in 2020 , maintenance work was carried out on the drainage system and some parts of it were renewed.

Disaster preparedness relating to Çankırı Museum's location (Table 2) was made by the use of the data obtained from the research.

Table 2. Disaster Preparedness relating to Çankırı Museum's Location

\begin{tabular}{|c|c|c|c|c|c|c|}
\hline Disaster & $\begin{array}{l}\text { Disaster } \\
\text { Source }\end{array}$ & $\begin{array}{l}\text { Probable Reason of } \\
\text { Hazard }\end{array}$ & $\begin{array}{l}\text { Yes/ } \\
\text { No }\end{array}$ & Affected & $\begin{array}{l}\text { Precaution on } \\
\text { Museum Structure }\end{array}$ & $\begin{array}{l}\text { Precaution } \\
\text { Value (PV) }\end{array}$ \\
\hline \multirow{3}{*}{$\begin{array}{l}\text { Earth- } \\
\text { quake (E) } \\
(14,28 / \\
14,28)\end{array}$} & \multirow{3}{*}{ Natural } & Soft and loose soil & Yes & $\begin{array}{l}\text { Building, } \\
\text { Artifact- } \\
\text { Relatively } \\
\text { (rel.) }\end{array}$ & \multirow{3}{*}{$\begin{array}{l}\text { Ground } \\
\text { reinforcement }\end{array}$} & \multirow{3}{*}{14,28} \\
\hline & & High seismic movement & No & $\begin{array}{l}\text { Building, } \\
\text { Artifact-rel. }\end{array}$ & & \\
\hline & & Earthquake zone & Yes & $\begin{array}{l}\text { Building, } \\
\text { Artifact-rel. }\end{array}$ & & \\
\hline \multirow{3}{*}{$\begin{array}{l}\text { Fire }(F) \\
(10,71 / \\
14,28)\end{array}$} & Natural & $\begin{array}{l}\text { Environmental } \\
\text { conditions such as very } \\
\text { high temperature and } \\
\text { low rainfall }\end{array}$ & No & $\begin{array}{l}\text { Building, } \\
\text { Artifact-rel. }\end{array}$ & Heat insulation & 3,57 \\
\hline & \multirow{2}{*}{$\begin{array}{l}\text { Human } \\
\text { related }\end{array}$} & \multirow{2}{*}{$\begin{array}{l}\text { Nearby buildings with } \\
\text { fire risk }\end{array}$} & \multirow{2}{*}{ No } & \multirow{2}{*}{$\begin{array}{l}\text { Building, } \\
\text { Artifact-rel. }\end{array}$} & $\begin{array}{lr}\text { Establishment } & \text { of } \\
\text { automatic } & \text { fire } \\
\text { extinguishing system }\end{array}$ & 0 \\
\hline & & & & & $\begin{array}{l}\text { Establishment of } \\
\text { smoke and heat } \\
\text { detection systems }\end{array}$ & 3,57 \\
\hline
\end{tabular}




\begin{tabular}{|c|c|c|c|c|c|c|}
\hline & & & & & $\begin{array}{ll}\text { with } & \text { central } \\
\text { monitoring } & \end{array}$ & \\
\hline & & $\begin{array}{l}\text { High crime zone, } \\
\text { sabotage }\end{array}$ & No & $\begin{array}{l}\text { Building, } \\
\text { Artifact-rel. }\end{array}$ & Security systems & 3,57 \\
\hline \multirow{4}{*}{$\begin{array}{l}\text { Flood (Fl) } \\
(7,14 / \\
14,28)\end{array}$} & \multirow{4}{*}{ Natural } & Flood area formerly & No & $\begin{array}{l}\text { Building, } \\
\text { Artifact-rel. }\end{array}$ & \multirow{3}{*}{$\begin{array}{l}\text { Establishing } \\
\text { drainage system } \\
\text { running smoothly }\end{array}$} & \multirow{3}{*}{7,14} \\
\hline & & Low rainfall / snowfall & No & $\begin{array}{l}\text { Building, } \\
\text { Artifact-rel. }\end{array}$ & & \\
\hline & & $\begin{array}{l}\text { Changable rain and snow } \\
\text { melting layout }\end{array}$ & No & $\begin{array}{l}\text { Building, } \\
\text { Artifact-rel. }\end{array}$ & & \\
\hline & & $\begin{array}{l}\text { Severe meteorological } \\
\text { events formerly }\end{array}$ & No & $\begin{array}{l}\text { Building, } \\
\text { Artifact-rel. }\end{array}$ & $\begin{array}{l}\text { Examination of } \\
\text { severe } \\
\text { meteorological } \\
\text { events in the past in } \\
\text { the region and } \\
\text { determination of the } \\
\text { time period likely to } \\
\text { recur }\end{array}$ & 0 \\
\hline \multirow{2}{*}{$\begin{array}{l}\text { Land- } \\
\text { slide (L) } \\
(14,28 / \\
14,28)\end{array}$} & \multirow[t]{2}{*}{ Natural } & Soft and loose soil & Yes & $\begin{array}{l}\text { Building, } \\
\text { Artifact-rel. }\end{array}$ & \multirow{2}{*}{$\begin{array}{l}\text { Ground } \\
\text { reinforcement } \\
\text { according } \\
\text { geological } \\
\text { measurements }\end{array}$} & \multirow{2}{*}{14,28} \\
\hline & & Landslide area & No & $\begin{array}{l}\text { Building, } \\
\text { Artifact-rel. }\end{array}$ & & \\
\hline $\begin{array}{l}\text { Tsunami } \\
\text { (T) } \\
\text { (Not } \\
\text { Applicabl } \\
\text { e) [N/A] }\end{array}$ & Natural & Location by the sea & No & $\begin{array}{l}\text { Building, } \\
\text { Artifact-rel. }\end{array}$ & $\begin{array}{l}\text { Examination of } \\
\text { tsunamis in the past } \\
\text { in the region and } \\
\text { determination of the } \\
\text { time period likely to } \\
\text { recur }\end{array}$ & $(\mathrm{N} / \mathrm{A})$ \\
\hline $\begin{array}{l}\text { Volcanic } \\
\text { action (V) } \\
(\mathrm{N} / \mathrm{A})\end{array}$ & Natural & Location by the volcano & No & $\begin{array}{l}\text { Building, } \\
\text { Artifact }\end{array}$ & $\begin{array}{l}\text { Examination of } \\
\text { volcanic actions in } \\
\text { the past in the region } \\
\text { and determination of } \\
\text { the time period likely } \\
\text { to recur }\end{array}$ & $(\mathrm{N} / \mathrm{A})$ \\
\hline $\begin{array}{l}\text { Rock falls } \\
\text { (R) (N/A) }\end{array}$ & Natural & Location by the rocky hill & No & $\begin{array}{l}\text { Building, } \\
\text { Artifact-rel. }\end{array}$ & $\begin{array}{l}\text { Rock stabilising and } \\
\text { strengthening }\end{array}$ & $(\mathrm{N} / \mathrm{A})$ \\
\hline
\end{tabular}

Calculations are made as follows:

'Disaster number' (D) is the total number of the rows including the 'disasters' likely to happen. This value is found by the sum of the disaster number of Table 1 and Table 2 (Equation 1). Tsunami, volcanic action and rock falls are not applicable for Çankırı Museum, so they are out of scope. 100 is divided to the total number of 'disasters' likely to happen for Çankırı Museum and the result is the 'disaster value' (Equation 2).

$$
\begin{gathered}
\text { Disaster Number }=\text { Disaster Number of Table } 1+\text { Disaster Number of Table } 26 \\
D=D 1+D 2 \\
\text { (Equation 1) } \\
7=4+3 \\
100 / \text { Disaster Number }=\text { Disaster Value } \\
100 / D=D V \\
100 / 7=14,28
\end{gathered}
$$


For every 'disaster', a number of 'precautions on museum structure' (P) is suggested in the tables. The 'precaution value' (PV) for the every fulfilled 'precaution' is calculated by dividing the 'disaster value' (DV) $(14,28)$ to the number of the 'precautions on museum structure' (P) (Equation 3). The fulfilled precautions for every disaster has the calculated value, and the unfulfilled precaution has got zero $(0)$ value. The values of earthquake, fire, flood and landslide are counted by the sum of the PV for each row (Equation 4,5,6 and 7, respectively).

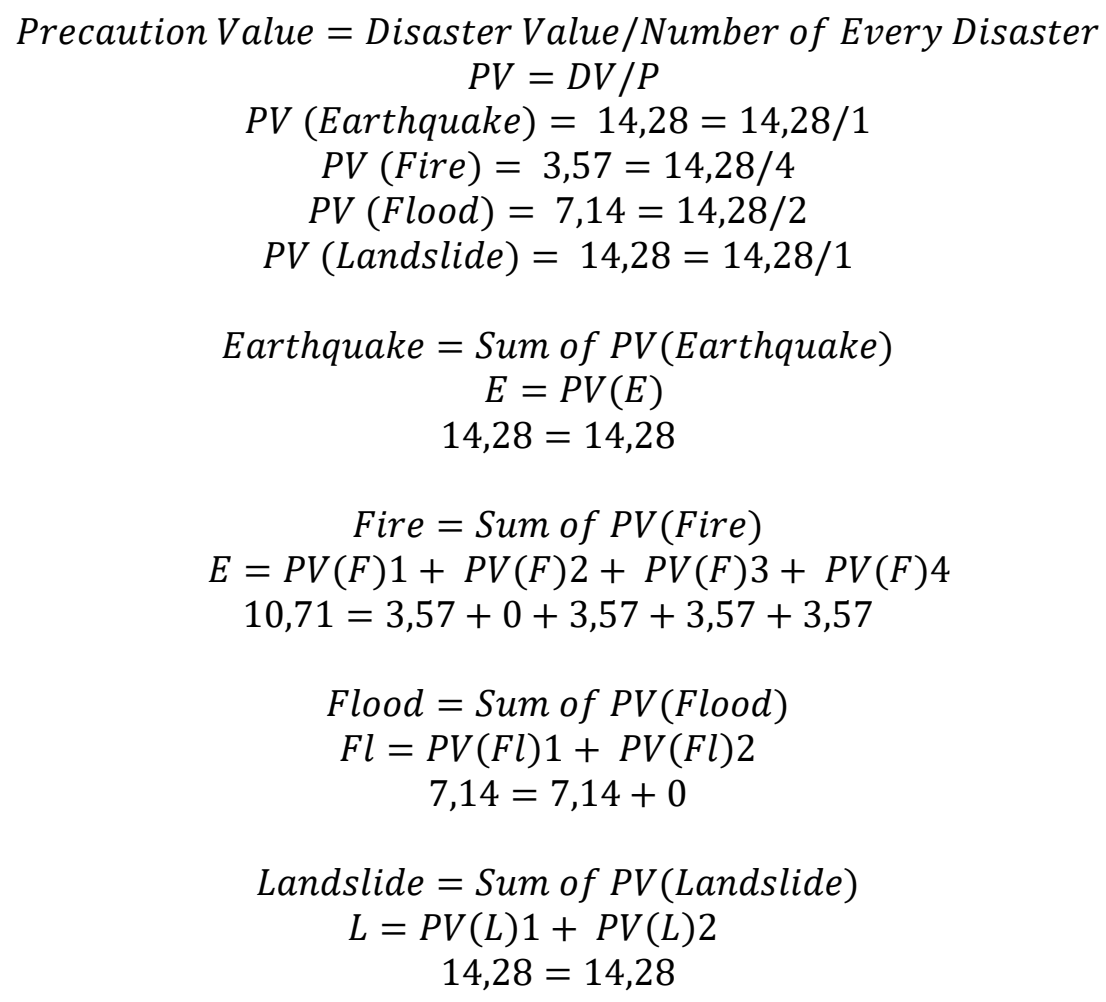

(Equation 3)

(Equation 4)

(Equation 5)

(Equation 6)

While evaluating Table 2, the below formula is used and disaster preparedness level relating to Çankırı Museum's location is calculated as 46,41 (Equation 8):

$$
\begin{aligned}
& \text { Disaster Preparedness Level relating to Location } \\
& =\text { Earthquake }+ \text { Fire }+ \text { Flood }+ \text { Landslide }+ \text { Tsunami } \\
& + \text { Volcanic Action }+ \text { Rock falls } \\
& \text { DPL }=E+F+F l+L+T+V+R \\
& 46,41=14,28+10,71+7,14+14,28+N / A+N / A+N / A
\end{aligned}
$$

When the hazards arising from the Çankırı Museum building are considered, firstly, an earthquake assessment should be done for the structure. Reporting regarding the earthquake resistance of the museum building; and necessary reinforcements were made within the restoration works carried out between 2014 and 2016. Gaps were opened in the interior walls in order to provide circulation between the exhibition spaces within the context of exhibition design. It is determined that the exhibition spaces are wide enough. The corridors on the floors are also used for display purposes and not only for passing so as to create reserve spaces in case of collection growth. These interventions are decided to be the measures to protect the artifacts from collapses, incorrect contacts and impacts because of earthquake.

As for fire resistance, the fire resistance of the building materials and the spread of fire are among the problems encountered in the historical buildings. The breakdowns in the electrical system were encountered in Çankırı Museum building before it was converted into a museum. Thus; as part of the restoration between 2014 and 2016, electrical installations were renewed. There is no 
automatic fire extinguishing system because it can be harmful for the artifacts. Instead, there are fire cabinets. There are also smoke detectors inside and in the wooden attic. Artifact storage doors are fire resistant steel doors. Loading area on the basement floor could be used as a fire exit. The spread of the fire to the other spaces cannot be controlled in the museum because there is no air tightness between the spaces. There is no system established to automatically or manually cut the natural gas flow to the building during an earthquake.

Spate hazard arising from the museum structure may occur due to reasons such as water leakage from the roof and ceiling, windows with water leakage, malfunction in the technical rooms in the basement and the plumbing (Canadian Conservation Institute, 2015). In the Çankırı Museum, the use of a sloping roof, eaves, rain gutter, insulation on the roof, the lack of artifact storage spaces on the top floor and the presence of a space for equipment to be used in spate are the precautions in the museum structure. There is a room for the materials to be used in case of spate. There isn't any inner area that would cause water accumulation. Since the artifact storages are located in the basement, there may be deterioration risk of the artifacts due to water in case of malfunctions in the technical rooms. There is no wet area next to the artifact storage spaces. There is no sanitary system in artifact exhibition and storage spaces. Breakdowns in the sanitary system in the other spaces were encountered before it was converted into a museum; hence sanitary installations were renewed as a part of the restoration between 2014 and 2016 (Ankara Directorate for Surveying and Monuments, 2021).

Disaster preparedness of Çankırı Museum building (Table 3) was made by the use of the data obtained from the research.

Table 3. Disaster preparedness of Çankırı Museum Building

\begin{tabular}{|c|c|c|c|c|c|c|}
\hline Disaster & $\begin{array}{l}\text { Disaster } \\
\text { Source }\end{array}$ & $\begin{array}{l}\text { Probable Reason of } \\
\text { Hazard }\end{array}$ & $\begin{array}{l}\text { Yes/ } \\
\text { No }\end{array}$ & Affected & $\begin{array}{l}\text { Precaution on } \\
\text { Museum Structure }\end{array}$ & PV \\
\hline \multirow{4}{*}{$\begin{array}{l}\text { Earth- } \\
\text { quake } \\
\text { (E) } \\
(10,71 / \\
14,28)\end{array}$} & \multirow{4}{*}{$\begin{array}{l}\text { Natural } \\
\text { Related }\end{array}$} & \multirow[t]{2}{*}{$\begin{array}{l}\text { Not Resillient to } \\
\text { Earthquake }\end{array}$} & \multirow[t]{2}{*}{ Yes } & \multirow{2}{*}{$\begin{array}{l}\text { Building, } \\
\text { Artifact- } \\
\text { rel. }\end{array}$} & $\begin{array}{l}\text { Making durability tests } \\
\text { of the building; } \\
\text { strengthening the } \\
\text { structure if necessary }\end{array}$ & 3,57 \\
\hline & & & & & $\begin{array}{l}\text { The use of seismic base } \\
\text { isolators on the ground }\end{array}$ & 0 \\
\hline & & & & & $\begin{array}{l}\text { Design of the exhibition } \\
\text { spaces }\end{array}$ & 3,57 \\
\hline & & $\begin{array}{l}\text { The exhibition spaces } \\
\text { are not wide enough }\end{array}$ & Yes & Artifact & $\begin{array}{l}\text { Establishment } \\
\text { appropriate exhibition } \\
\text { or artifact storage } \\
\text { places with the reserve } \\
\text { areas to collection } \\
\text { growth }\end{array}$ & 3,57 \\
\hline \multirow{5}{*}{$\begin{array}{l}\text { Fire (F) } \\
(6,12 / \\
14,28)\end{array}$} & \multirow{5}{*}{$\begin{array}{l}\text { Natural, } \\
\text { Human } \\
\text { Related }\end{array}$} & $\begin{array}{l}\text { Building materials not } \\
\text { resistant to fire }\end{array}$ & Yes & $\begin{array}{l}\text { Building, } \\
\text { Artifact- } \\
\text { rel. }\end{array}$ & $\begin{array}{l}\text { Using fire resistant } \\
\text { building materials }\end{array}$ & 0 \\
\hline & & $\begin{array}{l}\text { Random storage of } \\
\text { flammable materials }\end{array}$ & No & $\begin{array}{l}\text { Building, } \\
\text { Artifact- } \\
\text { rel. }\end{array}$ & $\begin{array}{l}\text { Creating a place where } \\
\text { flammable materials } \\
\text { are stored }\end{array}$ & 0 \\
\hline & & \multirow{3}{*}{$\begin{array}{l}\text { In the event of a fire, } \\
\text { the spread of the fire } \\
\text { to other places }\end{array}$} & \multirow{3}{*}{ Yes } & \multirow{3}{*}{$\begin{array}{l}\text { Building, } \\
\text { Artifact }\end{array}$} & $\begin{array}{l}\text { Air tightness of the } \\
\text { spaces }\end{array}$ & 0 \\
\hline & & & & & $\begin{array}{l}\text { Fire doors that opened } \\
\text { directly to the outside } \\
\text { of the venues }\end{array}$ & 2,04 \\
\hline & & & & & $\begin{array}{l}\text { Fire resistant storage } \\
\text { doors }\end{array}$ & 2,04 \\
\hline
\end{tabular}




\begin{tabular}{|c|c|c|c|c|c|c|}
\hline & & $\begin{array}{l}\text { Disturbances in the } \\
\text { electrical system }\end{array}$ & Yes & $\begin{array}{l}\text { Building, } \\
\text { Artifact- } \\
\text { rel. }\end{array}$ & $\begin{array}{l}\text { Establishment } \\
\text { regular of } \\
\text { systems and use of } \\
\text { cables suitable for } \\
\text { coding }\end{array}$ & 2,04 \\
\hline & & $\begin{array}{l}\text { Failure to stop natural } \\
\text { gas supply in } \\
\text { earthquake }\end{array}$ & No & $\begin{array}{l}\text { Building, } \\
\text { Artifact- } \\
\text { rel. }\end{array}$ & $\begin{array}{l}\text { Establishment of a } \\
\text { system that } \\
\text { automatically or } \\
\text { manually cuts the } \\
\text { natural gas flow to the } \\
\text { building during an } \\
\text { earthquake }\end{array}$ & 0 \\
\hline \multirow{15}{*}{$\begin{array}{l}\text { Flood } \\
(\mathrm{Fl}) \\
(8,55 / \\
14,28)\end{array}$} & \multirow{15}{*}{$\begin{array}{l}\text { Natural, } \\
\text { Human } \\
\text { Related }\end{array}$} & \multirow{7}{*}{$\begin{array}{l}\text { Water leakage from } \\
\text { the roof and ceiling }\end{array}$} & \multirow{7}{*}{ Yes } & \multirow{7}{*}{$\begin{array}{l}\text { Building, } \\
\text { Artifact }\end{array}$} & $\begin{array}{l}\text { Regular cleaning of rain } \\
\text { gutters }\end{array}$ & 0,95 \\
\hline & & & & & Pitched roof & 0,95 \\
\hline & & & & & Roof insulation & 0,95 \\
\hline & & & & & $\begin{array}{l}\text { Use of suitable and } \\
\text { sufficient insulation } \\
\text { materials }\end{array}$ & 0 \\
\hline & & & & & $\begin{array}{l}\text { Suitable details in } \\
\text { ceiling openings }\end{array}$ & 0 \\
\hline & & & & & $\begin{array}{l}\text { Not placing the artifact } \\
\text { storage spaces in the } \\
\text { attic }\end{array}$ & 0,95 \\
\hline & & & & & $\begin{array}{l}\text { Space for equipment to } \\
\text { be used in spate }\end{array}$ & 0,95 \\
\hline & & \multirow[t]{2}{*}{$\begin{array}{l}\text { Water leakage from } \\
\text { the windows }\end{array}$} & \multirow[t]{2}{*}{ Yes } & \multirow[t]{2}{*}{$\begin{array}{l}\text { Building, } \\
\text { Artifact }\end{array}$} & $\begin{array}{l}\text { Use of suitable and } \\
\text { sufficient insulation } \\
\text { materials }\end{array}$ & 0 \\
\hline & & & & & Suitable details & 0,95 \\
\hline & & $\begin{array}{l}\text { Spate to occur as a } \\
\text { result of breakdown } \\
\text { in technical rooms } \\
\text { such as the boiler } \\
\text { room, water } \\
\text { distribution system in } \\
\text { the basement }\end{array}$ & No & $\begin{array}{l}\text { Building, } \\
\text { Artifact }\end{array}$ & $\begin{array}{l}\text { Not placing the storage } \\
\text { spaces in the basement }\end{array}$ & 0 \\
\hline & & \multirow{3}{*}{$\begin{array}{l}\text { Plumbing } \\
\text { malfunctions }\end{array}$} & \multirow{3}{*}{ Yes } & \multirow{3}{*}{$\begin{array}{l}\text { Building, } \\
\text { Artifact- } \\
\text { rel. }\end{array}$} & $\begin{array}{l}\text { Easily accessible and } \\
\text { well organized sanitary } \\
\text { system for quick } \\
\text { inspection }\end{array}$ & 0,95 \\
\hline & & & & & $\begin{array}{l}\text { Absence of plumbing in } \\
\text { artifact exhibition and } \\
\text { storage spaces }\end{array}$ & 0,95 \\
\hline & & & & & $\begin{array}{l}\text { Not placing the storage } \\
\text { spaces next to or under } \\
\text { wet areas }\end{array}$ & 0,95 \\
\hline & & \multirow{2}{*}{$\begin{array}{l}\text { Places that cause } \\
\text { water accumulation } \\
\text { in the building }\end{array}$} & \multirow[t]{2}{*}{ No } & \multirow{2}{*}{$\begin{array}{l}\text { Building, } \\
\text { Artifact- } \\
\text { rel. }\end{array}$} & $\begin{array}{l}\text { Water proofing around } \\
\text { the Mechanical } \\
\text { Equipment Room }\end{array}$ & 0 \\
\hline & & & & & Water insulated floor & 0 \\
\hline
\end{tabular}

While evaluating Table 3, the below formula is used (Equation 5). Disaster value was found as 14,28 (Equation 2). The 'precaution value' (PV) for the every fulfilled 'precaution' is calculated by dividing the 'disaster value' (DV) to the number of the 'precautions on museum structure' (P) 
(Equation 3). The fulfilled precautions for every disaster has the calculated value, and the unfulfilled precaution has got zero $(0)$ value. The values of earthquake, fire, flood and landslide are counted by the sum of the PV for each row (Equation 4,5,6 and 7, respectively). Disaster preparedness level relating to building is counted as 25,38 (Equation 9).

$$
\begin{aligned}
& \text { Precaution Value }=\text { Disaster Value } / \text { Number of Every Disaster } \\
& P V=D V / P \\
& P V(\text { Earthquake })=3,57=14,28 / 4 \\
& P V(\text { Fire })=2,04=14,28 / 7 \\
& P V(\text { Flood })=7,14=14,28 / 2 \\
& P V(\text { Landslide })=0,95=14,28 / 15 \\
& \text { Earthquake }=\text { Sum of PV(Earthquake) } \\
& E=P V(E) 1+P V(E) 2+P V(E) 3+P V(E) 4 \\
& 10,71=3,57+0+3,57+3,57+3,57 \\
& \text { Fire }=\text { Sum of PV(Fire }) \\
& F=P V(F) 1+P V(F) 2+P V(F) 3+P V(F) 4+P V(F) 5+P V(F) 6+P V(F) 7 \quad \text { (Equation 5) } \\
& 6,12=0+0+0+2,04+2,04+2,04+0 \\
& \text { Flood }=\text { Sum of PV(Flood }) \\
& F l=P V(F l) 1+P V(F l) 2 \\
& 8,55=0,95+0,95+0,95+0+0+0,95+0,95+0+0,95+0+0,95+00,95+0,95+0+0 \\
& \text { Disaster Preparedness Level relating to Building }=\text { Earthquake }+ \text { Fire }+ \text { Flood } \\
& D P B=E+F+F l \\
& 25,38=10,71+6,12+8,55
\end{aligned}
$$

Eventually, disaster preparedness level is calculated by the below formula and calculated as 71,79 (Equation 10):

$$
\begin{gathered}
\text { Disaster Preparedness Level = Disaster Preparedness Level relating to Location }+ \\
\text { Disaster Preparedness Level relating to Building } \\
D P=D P L+D P B \\
71,79=46,41+25,38
\end{gathered}
$$

DP is determined as 71,79 in the system of 100 , which is a high degree according to Table 1 . The necessary precautions are evaluated as taken at a high rate for the disasters in scope of Çankırı Museum.

\section{CONCLUSION}

As known, museums are exposed to natural and human-made disasters, which give harm to the museum building and the collection. It is important to provide the participation of a large number of people from management to visitors and volunteers in context of the preventive conservation and to create protection awareness (Rose and Hawks, 1995). The hazards encountered in museums cause various risks with regards to the health of the museum artifacts and the historical building. These hazards may arise from the location of the museum as well as the museum building. In the restoration works on the registered immovable cultural properties, implementations are limited. However, there is a necessity for the rehabilitation of historical buildings according to the museology and today's needs. 
The findings made regarding the hazards that may arise during the conversion of the historical building into the Çankırı Museum were determined by examining the hazard sources, hazard types and the precautions taken against them. Çankırı Museum is chosen for the disaster risk assessment because of its historical identity and its recent restoration and transformation. A grading system is proposed to determine if the museum and the artifacts are safe or not according to the data obtained from the research. As a result of the assessment according to the grading system, 'Disaster Preparedness Level of Çankırı Museum' is determined as 71,79 within the system of 100 . This is a high degree, which means that the necessary precautions are evaluated as taken at a high rate for the disasters in Çankırı Museum. As a precaution against earthquake, required applications were mainly done; such as ground reinforcement and strengthening the building. Since it is not mainly possible to apply insulation materials to the original walls or basement in the historical building, indoor climatic control should be provided with devices. However, heat insulation was applied in the inner walls in between the timber frame as an infill in Çankırı Museum. A place for the storage of the materials could be assigned. A system that automatically or manually cuts the natural gas flow to the building in case of an earthquake would be useful as a precaution against fire.

The necessary precautions could be determined thanks to the disaster preparedness tables prepared as a checklist. It is aimed to minimize the risks to the health of the museum artifacts and the historical buildings during the conversion of the buildings through the use of the assessment tables.

Acknowledgments: I express my gratitude to Emine Aydın and Atilla Can for their contributions; Seda Duzcu for proofreading and Ömer Doğruer for his guidance for the grading system and proofreading.

\section{REFERENCES}

Ankara Directorate for Surveying and Monuments. (2021). Archive Resourses. Ankara. Turkey.

Appelbaum , B. (1991). Guide to environmental protection of collections, U.S.A.: Sound View Press.

Canadian Conservation Institute. (2015). Framework for prevention of collections. Poster. Canada: Canadian Conservation Institute.

Cassar, M. (1999). Environmental management, guidelines for museums and galleries, U.K.: Museums \& Galleries Commision.

Demircioğlu, Z. (1973). Kastamonu Valileri (1881-1908). Kastamonu: Doğrusöz Matbaası.

Demiröz, A. (2001). 1893-1969 Fotoğraflarla Çankırı. Çankırı.

Doğruer, F.S. (2019). Investigation of museum designs within preventive conservation context in Turkey's selected museums containing archaeological artifacts. (Unpublished Ph. D. Dissertation, Gazi University). Council of Higher Education, Thesis Center.

Duymaz, A.Ş. (2003). II.Abdülhamid döneminde imar faaliyetleri. (Unpublished Ph. D. Dissertation, Süleyman Demirel University). Council of Higher Education, Thesis Center.

General Directorate for Cultural Heritage and Museums. (2021). Archive Resourses. Ankara. Turkey.

International Council of Museums (ICOM). (2017). Code of ethics for museums. Paris: ICOM Publications.

Kocaeli, F. (2017). Karakteristik örnekleriyle İç Anadolu Bölgesi müzelerinde önleyici koruma sorunları üzerine bir değerlendirme. (Unpublished Master's Thesis, Gazi University). Council of Higher Education, Thesis Center. 
Kökten, H. (2007). Müzede koruma. In B.Eskici, S.Çelik, D.Hepdinç, H.Kökten, \& Y.S. Şener, (Eds.), Müzelerde önleyici koruma uzaktan eğitim programı. (pp. 25-149). Ankara: Ankara Üniversitesi Uzaktan Eğitim Yayınlarl.

Kuzucuoğlu, A.H. (2010). Müzelerde iklim ölçümleri ve pasif konservasyon; Restorasyon-Konservasyon Çalıșmaları Dergisi, 6, 17-22.

Liston, D. (2000). Museum security and protection, a handbook for cultural heritage institutions. ICOM \& the International Committee on Museum Security.

National Park Service. (2006). Museum hand book. Part I. U.S.A.: National Park Service Publications.

Özkan Yazgan, F.S. (2011). Anıtsal kültür varlıklarının müze olarak kullanımına yönelik yaklaşımın İstanbul İbrahim Paşa Sarayı örneğinde irdelenmesi. (Unpublished Ph. D. dissertation, Gazi University). Council of Higher Education, Thesis Center.

Pedersoli, J. L.; Antomarchi C.; Michalski, S. (2016). A guide to risk management of cultural heritage. ICCROM \& Canadian Conservation Institute.

Podany, J. (2001). Seismic security for museum collections. Lecture Notes of Education on Disaster Preparedness. İstanbul: Boğaziçi University, Kandilli Observatory and Earthquake Research Institute.

Roberts B.O \& Hutchins, J.K. (2009). Disaster risk management for museums. Cultural heritage protection handbook 4. Paris: UNESCO Publications.

Rose C.L.; Hawks C.A. (1995). A preventive conservation approach to the storage of collections, In C.L. Rose, C.A. Hawks \& H.H. Genoways (Eds.), Storage of natural history collections: a preventive conservation approach (pp. 1-33). Chicago: Society for the Preservation of Natural History Collections.

Sungay, S.B. (2012). Müzeler için afet ve acil durum planı kılavuzu. (Unpublished Master's Thesis, İstanbul Technical University). Council of Higher Education, Thesis Center.

Topçubaşı, M. (2009). 19. yüzyılda Kastamonu Eyaleti'nde kamu yapıları ve yeniden kullanım sorunları. (Unpublished Ph. D. dissertation, İstanbul Technical University). Council of Higher Education, Thesis Center.

URL 1, Culture Portal. (2021). https://kulturportali.gov.tr (Last Accessed: 05.01.2021).

URL 2, Çankırı Governorship. (2021). http://www.cankiri.gov.tr/cankiri-muzesi (Last Accessed: 05.01.2021).

URL 3, Disaster and Emergency Management Presidency (AFAD) Annotated Disaster Management Glossary. https://www.afad.gov.tr/aciklamali-afet-yonetimi-terimleri-sozlugu (Last Accessed: 28.04.2021).

URL 4, General Directorate for Cultural Heritage and Museums. (2021). https://kvmgm.ktb.gov.tr/TR44079/cankiri-muze-mudurlugu.html (Last Accessed: 05.01.2021).

https://www.vgm.gov.tr/organizasyonlar/tarihi-yapilarda-deprem-risklerinin-yonetimi-uluslararasi

URL 5, International Council on Monuments and Sites (ICOMOS) (2010). Lima Declaration for Disaster Risk Management of Cultural Heritage. http://www.icomos.org.tr/Dosyalar/ICOMOSTR en0621998001587380717.pdf $\quad$ (Last Accessed: 02.04.2021).

URL 6, International Scientific Committee on Risk Preparedness (ICORP) \& Ylldı Technical University of Istanbul (YTU). (2012) Statement. International Symposium on Cultural Heritage Protection in Times of Risk: Challenges and Opportunities, 15 - 17 November, 2012 at Yildiz Technical University, Istanbul, Turkey. http://icorp.icomos.org/wp-content/uploads/2017/05/ICORP-Istanbul-Statement-2012.pdf $\quad$ (Last Accessed: 30.04.2021). 
URL 7, Istanbul Governorship. (2014). The Giant Project of Istanbul: ISMEP. https://www.ipkb.gov.tr/wpcontent/uploads/2019/07/ISMEP dergi ENG 2208d\%C3\%BCs\%C3\%BCk.pdf (Last Accessed: 01.08.2021).

URL 8, Jigyasu, R. \& Arora, V. (2013). Disaster Risk Management of Cultural Heritage in Urban Areas, A Training Guide. Research Center for Disaster Mitigation of Urban Heritage, UNESCO World Heritage Centre, ICCROM \& Ritsumeikan University, Kyoto, Japan. https://www.preventionweb.net/files/44208 trainingguide1.pdf (Last Accessed: 02.04.2021).

URL 9, Meteorological Service. (2021). Environmental condition statistics of Çankırı (Turkey) https://www.mgm.gov.tr/veridegerlendirme/il-ve-ilceler-istatistik.aspx?k=undefined\&m=CANKIRI haritasi (Last Accessed: 11.01.2021).

URL 10, UNESCO. (2021). International Symposium of Cultural Heritage Protection in Times of RiskChallenges and Opportunities https://whc.unesco.org/en/events/894/ (Last Accessed: 11.01.2021).

URL 11, General Directorate for Foundations. (2021). International Symposium on Earthquake Risk Management of Historical Structures https://www.vgm.gov.tr/organizasyonlar/tarihi-yapilarda-depremrisklerinin-yonetimi-uluslararasi (Last Accessed: 11.01.2021). 